\title{
Update on the Vanuatu Megapode Megapodius layardi on Ambrym, Vanuatu
}

\author{
TANYA FOSTER
}

\section{Summary}

A group of villagers in Vanuatu are concerned that continuing development pressures are contributing to the over-exploitation of eggs of the Vanuatu Megapode Megapodius layardi. The Vanuatu Megapode or "namalau" as it is known locally, is endemic to the country and classified as Vulnerable. Repeating a previous survey carried out in 1995, the Vanuatu Protected Areas Initiative mapped and classified the burrows at three communal nesting grounds on north-west Ambrym in November 1996. The number of active and probably active burrows on the beach was low compared with 1995, whereas it was higher on both the raised promontories. The beach nesting site had recently been affected by a cyclone, and storm waves had inundated the area with the highest concentration of burrows. There is concern over the high percentage of megapode burrows checked by villagers at Buwoma, as well as the localized impact visitors could be having. Discussions with villagers raised useful points to be included in the proposed protection plan, particularly the support for a protected area.

\section{Introduction}

Vanuatu is a Y-shaped archipelago in the south-west Pacific. Ambrym is one of the central islands in Vanuatu, and the ground substrate of the area is composed of black ash originating from the two active volcanoes inland. In November 1996 the Vanuatu Protected Areas Initiative (VPAI) repeated surveys conducted in 1995 (Bowen 1996) of nesting grounds of the Vanuatu Megapode Megapodius layardi on the north-west coast of Ambrym. The British VPAI team had previously visited Ambrym in February 1995 in response to local people's concerns that there was over-exploitation of megapode eggs (a rich protein source) from the Buwoma beach area. The Vanuatu Megapode is a priority species in the Megapode Action Plan 1995-1999 (Dekker and McGowan 1995) and due to its limited distribution is classified as Vulnerable by Collar et al. (1994) and Jones et al. (1995).

In 1995 VPAI had chosen three active communal nesting grounds, mapped the burrows and calculated densities of "active", "probably active" and "old" burrows (Bowen 1996). Discussions with ni-Vanuatu from 19 villages near the nesting grounds provided valuable information on this little studied species. Through these discussions it became evident that the traditional tabus used successfully in the past by landowners are no longer respected by locals visiting the nesting area. This is partly due to the area being uninhabited and its ownership disputed. 
Table 1. Classification of the burrows of the Vanuatu Megapode

\begin{tabular}{|c|c|c|}
\hline \multicolumn{2}{|c|}{ Burrow category } & Description \\
\hline & urrow & Characteristic indentation or tunnel in the ground \\
\hline A & Active & $\begin{array}{l}\text { (1) Stick sinks easily into loose soil underground (confirmed by the } \\
\text { pile to one side of freshly dug earth) or (2) Megapode seen digging } \\
\text { at or emerging from the burrow }\end{array}$ \\
\hline PA & Probably Active & $\begin{array}{l}\text { (1) Stick sinks into the ground but the soil is fairly compact or (2) } \\
\text { Megapode footprints around the burrow entrance but soil is fairly } \\
\text { compact }\end{array}$ \\
\hline $\mathrm{O}$ & Old & Ground compact and hard and no piles of recently dug earth \\
\hline
\end{tabular}

Revised since Bowen (1996); footprints do not confirm a nest is "active", and since leaf litter within burrows was negligible it was omitted.

Since many villagers support the proposal for a management plan to control the number of eggs being collected at the Buwoma area, VPAI aims to assist in its implementation. To assess the status and threats to the Vanuatu Megapode, VPAI plans to resurvey the three nesting sites and compare burrow activity every two years; to record behavioural observations and to continue collecting new information from the local people. In particular, VPAI needs to establish the extent of man's direct impact on the megapode population. The November 1996 survey was the first of these repeat surveys.

\section{Methods}

In 1996 we used Global Positioning System coordinates to re-locate the three sections of nesting ground surveyed in 1995 on Ambrym. We used compass bearings and descriptive natural markers to re-locate the paths on the two promontories and the boundary of the grid on the beach. As before, we mapped the two sites on promontories in $20-\mathrm{m}$ bands on either side of the path and as a 90 $\mathrm{m}$ by $80 \mathrm{~m}$ grid on the beach (Bowen 1996). Within each of the sites we mapped and classified the burrows as "active", "probably active", or "old" (Table 1). Where several burrows were located close together, we counted and classified each burrow separately. We noted the location of the burrow (e.g. around the roots of a living tree), and any evidence of disturbance by man (boot prints, large pile of excavated earth). We measured the breadth, width, and depth (in relation to the surrounding ground level) of the excavated area around the burrows to allow a comparison between burrows checked by collectors and those dug only by megapodes.

We talked to groups visiting the Buwoma nesting grounds about the purpose of their trip. In addition, towards the end of November 1996 VPAI returned to the 11 villages in the north visited in 1995 to gather new information on the Vanuatu Megapode.

\section{Results}

Survey

Across the three sites 146 burrows were mapped (Table 2). If we include the 
Table 2. Number and densities per ha. of burrows per nesting site according to state of use

\begin{tabular}{|c|c|c|c|c|c|c|c|c|}
\hline \multirow[b]{2}{*}{ Site } & \multirow[t]{2}{*}{ Area (ha) } & \multicolumn{2}{|c|}{ Active burrows } & \multicolumn{2}{|c|}{ Probably Active } & \multicolumn{2}{|c|}{ Old burrows } & \multirow[b]{2}{*}{ Total $(n)$} \\
\hline & & $n$ & $\begin{array}{l}\text { Density } \\
\text { per ha }\end{array}$ & $n$ & $\begin{array}{l}\text { Density } \\
\text { per ha }\end{array}$ & $n$ & $\begin{array}{l}\text { Density } \\
\text { per ha }\end{array}$ & \\
\hline Promontory A & 0.34 & 38 & 111.8 & 18 & 52.9 & 16 & $47 \cdot 1$ & $7^{2}$ \\
\hline Promontory B & 0.23 & 21 & 91.3 & 12 & 52.2 & 22 & $95 \cdot 7$ & 55 \\
\hline Buwoma Beach & 0.67 & 4 & 6.0 & 6 & 9.0 & 9 & $13 \cdot 4$ & 19 \\
\hline Total & & 63 & & 36 & & 47 & & 146 \\
\hline
\end{tabular}

"probably active" burrows in our calculations, the number of burrows in use by megapodes was 56 for Promontory A (29 in 1995), 33 for Promontory B (27 in 1995), 10 for Buwoma Beach ( 28 in 1995). Some $68 \%$ of the burrows mapped were "active" or "probably active" (57\% in 1995). On Promontory A the number of active and probably active burrows was almost twice as high in 1996 compared with 1995; there was a smaller increase on Promontory B.

There is a clear decrease in the number of active and probably active burrows within the beach grid in 1996 (Figure 1 ) and a drop in the number of old burrows recorded ( 22 down to 9 ). Within $50 \mathrm{~m}$ of a cave that many visitors use as a day camp, only 2 burrows were found in use in 1996 (both probably active) compared with 3 active and 16 probably active burrows in 1995 .

Fewer than half the active and probably active burrows mapped in 1995 were recorded in those categories in 1996 (38\% on Promontory A, 48\% on Promontory $B, 18 \%$ on the Beach). Out of the 64 burrows mapped as old across the three sites in 1995, by 1996: $15.6 \%$ were remapped as old, and $79.6 \%$ could not be re-located.

All three nesting sites had a low percentage of active and probably active burrows mapped in 1996 that had been classified as in use 21 months previously (25\% on Promontory A, 39.4\% on Promontory B, 50\% at the Beach). By 1996, of the 47 burrows mapped as old, only $51 \%$ had been accounted for in $1995(30 \%$ had been active or probably active).

\section{Disturbance of the burrows by humans}

Villagers had checked the majority of burrows for eggs (93\% on Promontory A, $70 \%$ on Promontory B, $75 \%$ on the Beach). Villagers were present on each of the seven days we spent at Buwoma and on three days there was egg collecting. It took three men half a day to collect 45 eggs. Two other groups brought dogs to hunt wild pigs in the forest and one group spent four days camping near the Beach site, mainly fishing on the reef.

Since we were unable to measure individual excavations at locations with more than one burrow (23\% of locations had two, three or four burrows), we took measurements of the whole cluster. Both burrows and clusters of burrows we collectively called "nests". Most undisturbed nests were discreetly located and, on the promontories, were over $15 \mathrm{~m}$ from the path up a steep, slippery slope, whereas the nests dug by egg collectors were close to the path and enlarged (Table 3). 

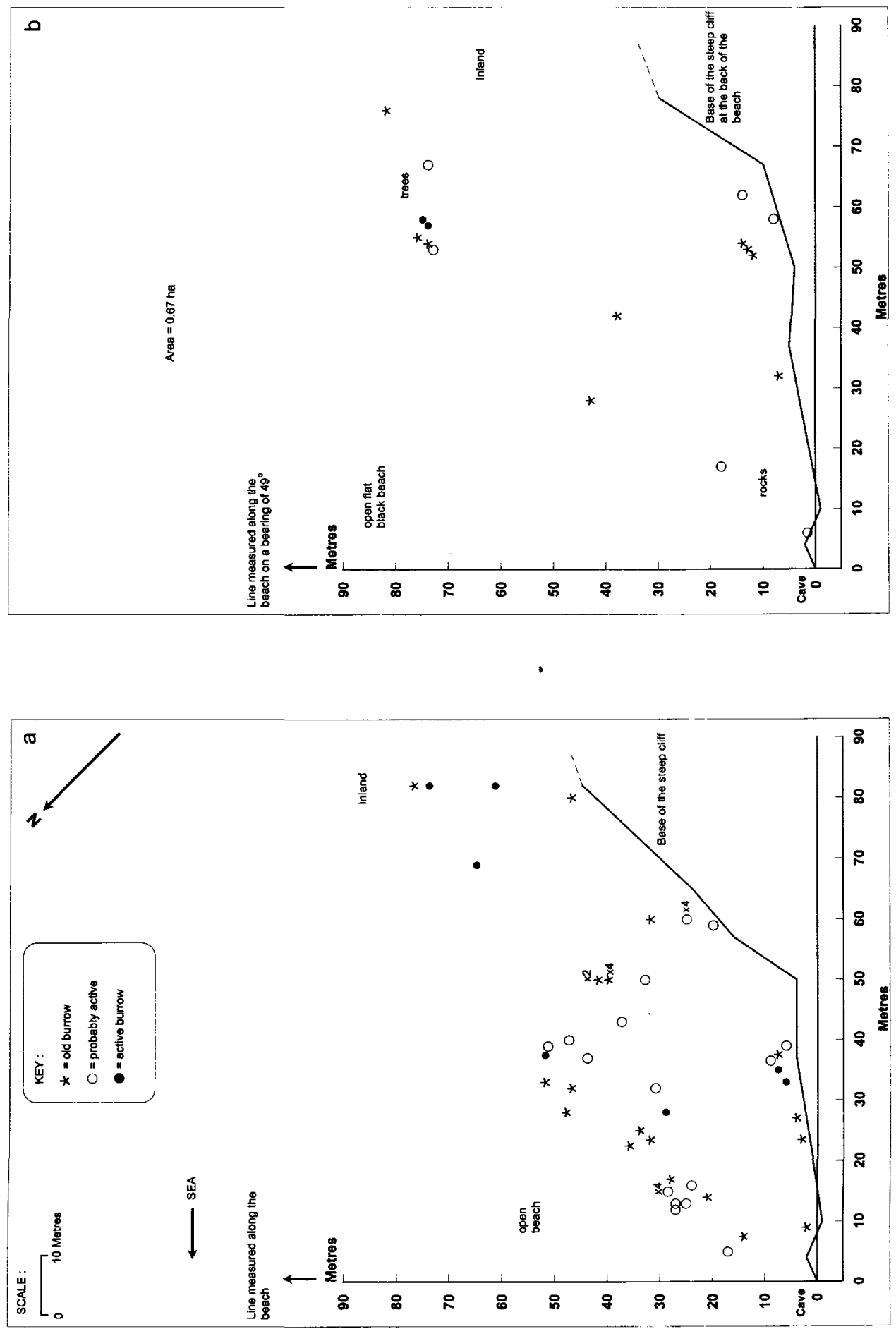
Table 3. Measurements of "nests" across the three sites

\begin{tabular}{|c|c|c|c|c|c|c|c|c|}
\hline & \multicolumn{3}{|c|}{$\begin{array}{l}\text { Nests checked by men } \\
n=54\end{array}$} & \multicolumn{3}{|c|}{$\begin{array}{l}\text { Nests not checked by men } \\
n=21\end{array}$} & \multicolumn{2}{|l|}{$\begin{array}{l}\text { Total } \\
n=75 \\
\end{array}$} \\
\hline & Range & Mean & S.D. & Range & Mean & S.D. & Mean & S.D. \\
\hline Depth (m) & $0.2-2.3$ & 0.75 & 0.38 & $0.2-1.6$ & 0.6 & 0.38 & 0.71 & 0.38 \\
\hline Breadth (m) & $0.2-2.2$ & 0.95 & 0.45 & $0.3-1.8$ & 0.87 & 0.42 & 0.93 & 0.44 \\
\hline Width (m) & $0.3-2.5$ & 1.08 & 0.54 & $0.2-2$ & 0.91 & 0.6 & 1.03 & 0.56 \\
\hline
\end{tabular}

\section{Environmental observations}

Since the 1995 survey, a storm in October 1996 had altered the profile of the Beach site and eroded more than $20 \mathrm{~m}$ at the eastern end of Promontory A. Heavy rain at the end of the week caused the powdery ash to solidify and we found it hard to dig into burrows we had mapped. By the scorch marks on the trunks of trees such as Acacia spirorbis, it was evident that an uncontrolled fire had swept through the area.

\section{Local information}

Our discussions verify that, in north-west Ambrym, megapode eggs are laid year round, peaking between June and November. At least four day trips are made annually by most villages; usually 2-7 men go and $40-300$ eggs are collected each trip. Digging of the burrows loosens the earth and the collectors claim this attracts the megapodes back to a particular nest. Most villages access Buwoma nesting grounds by motorized boat, although the inland village of Ranhor sent men on foot over the volcano.

The main concern of the village elders was the lack of respect for tabus implemented by landowners to control egg harvesting. Previously, eggs were harvested solely for consumption, now they are dug for commercial benefit, sometimes using shovels.

The collectors commented that storm waves in October had washed away many of the burrows at the beach and also the few below the path on Promontory A. They added that after heavy rain the ground becomes hard, making it difficult for the chicks to emerge and that they had found rotten eggs in burrows following storms. One villager commented that dogs brought for hunting wild pig were sometimes left behind at Buwoma and occasionally killed adult megapodes. Two men from different villages stated that fires were a main cause for the decline in megapodes at Buwoma. During our stay a group left a fire blazing at the Beach site.

It was mentioned that sometimes a chick found by collectors checking a burrow, would be taken back to the village and reared in a cage until large enough to eat. None were held in villages in the north-west at the time.

Figure 1. Location and classification of burrows of the Vanuatu Megapode surveyed at Buwoma Beach site in 1995(a) and 1996(b). Clustered burrows of the same category are marked with one symbol $x$ the number of burrows. 
It was also verbally confirmed that solitary megapode nests are scattered in the "bush" behind many of the villages. However, because they are spread out and harder to locate, the collectors prefer to visit the communal nesting sites at Buwoma. One exception is at Ranvetlam, where on one man's land there are reputed to be many nests in the bush. Others commented that, with the clearance of "dark bush", including the collection of wood, many of these nests have disappeared.

\section{Discussion}

Changes in the number of burrows in use since 1995

Reproductive data (including the number and category of burrows at different times of year) need to be collected before we can interpret the differences in burrow activity between the two surveys, and know for certain how often a female Vanuatu Megapode lays an egg and whether she uses the same burrow. However, since the locals are concerned about an apparent decline in the number of eggs and state that the birds lay eggs all year, it is important to assess causes other than seasonal variation.

The burrows recorded as "active" and "probably active" are assumed to be in use for egg laying. The decrease in the number of burrows in use on the Beach site, as well as the low percentage from 1995 re-recorded in use in 1996, could be attributed to several factors. First, according to collectors, only a few weeks before the survey an unusually heavy storm had inundated many of the burrows lower down the beach. Also rock-falls from the cliff had blocked the entrance of an active burrow and rendered part of the survey area unsuitable for megapode nesting. Second, the higher number of visitors over our seven days at Buwoma, as well as remnants of fires and rubbish found across the beach site, indicates an increase in men's presence and checking of burrows on the beach. It is near the cave that visitors roast hunted pig, seek shelter from rain, and allow their accompanying dogs to run around. Each of these could account for recently excavated burrows unrecorded in 1995 at the base of a higher cliff between the Beach site and Promontory A; they had been checked by men.

The decrease in the number of burrows in use on the Beach may be causing megapodes to re-locate burrows and contributing to the almost doubling of the number of burrows in use on the closer Promontory A. The number of burrows in use on Promontory B, the site least affected by the October storm waves, had increased by $22 \%$. This is in accordance with November being at the end of the peak laying season, whilst February (the survey period in 1995) is off peak. During the rainy season (November-April) cloud cover and rainfall reduce the temperature of the substrate and saturation of air spaces prevents gas exchange through the egg shell.

Sankaran (1995) used lower mound densities and a higher proportion of abandoned to active mounds to indicate population loss for the Nicobar Megapode Megapodius nicobariensis. Applying this to burrows at the Buwoma sites, the overall slight increase in the proportion of mapped burrows that are in use, along with increase in density of burrows on both the promontories, suggests the 
number of laying females has not decreased in the past 21 months. However, the survival rate of eggs to sexually mature adults is likely to have dropped over recent years due to the high number of burrows constantly being dug up by men. The negative effect on this megapode population may only become evident once the population levels are critical.

As soon as basic reproductive data are collected for the Vanuatu Megapode, we can assess the apparent marked changes in burrow usage between 1995 and 1996. Our burrow classifying system may need to be adjusted.

\section{Level of exploitation}

A high percentage of burrows across all three sites had signs that they had been checked for eggs. Shorter distances from the path and ease of access to burrows appears to increase the risk of exploitation by man. On Promontory A, where burrows are close together and to the path, the only active burrow not disturbed was discreetly hidden under dense bush. Although Promontory B supports a high number of active burrows and was intensely visited by collectors, the more complex nature of the habitat meant some burrows remained undisturbed. Between surveying days, men walking on the slopes had loosened the ash causing a couple of active nests to collapse. This will have conservation implications if increased visitor pressure causes soil erosion and compaction. On Buwoma Beach the four active burrows had been checked by men, four of six of the probably active ones had obviously been checked, and all five old burrows showed signs of having been exploited by man. From our measurements, the checking of burrows increases their size but we are unable to assess this impact.

\section{Other threats to the number of megapodes}

As discussed by Bowen (1996) the main threat to the Vanuatu Megapode on north-west Ambrym continues to be a decrease in suitable habitat at coastal nesting grounds due to encroaching agriculture and development. Bregulla (1992) also comments on the fracturing of the lowland forest where megapodes feed. The coastal road connecting villages in the north-west may be extended; this would have serious implications for the Buwoma nesting ground since its inaccessibility by road presently limits egg collection and development. As the people of Vanuatu are forced into a cash economy, the shift in motivation towards collecting eggs commercially raises concerns. Having evolved in habitats that were free of carnivores, Dekker (1989) notes that megapodes are particularly vulnerable to introduced predators including dogs left after hunting trips.

Fires are certainly a concern, since they will inhibit egg laying and alter the temperature of the nests. The solidifying and cooling effect of rain on the ash may have serious implications for the digging of burrows, embryo development, the emergence of chicks, and the timing of surveys to classify burrows. The susceptibility of Vanuatu to localized natural disasters including cyclones and volcanic activity, increases the vulnerability of this species if their habitat becomes restricted (Stattersfield et al. 1998), particularly if human threats increase. 
Protection plan for the Vanuatu Megapode on north-west Ambrym

Preparations for the plan include further consultations with local chiefs, landowners and egg collectors, as well as continued liason with the government Environment Unit and VEO (Vanuatu Orgenaiseisen Blong Envaeromen), a recently established environmental NGO. As an ongoing assessment of the status and threats to the megapode population, VPAI will continue to collate information and analyse data from the biennial surveys at the three sites. It would be useful to record a temperature profile for the nesting grounds to establish the availability and importance of geothermal heat at the sites (Dekker 1988).

The consensus during a discussion with villagers at Ramuhu, and approved by both landowners, was that it was feasible to completely protect a section of the Buwoma nesting grounds from egg harvesting. The alternative of attempting to limit the number of eggs collected across the whole of Buwoma requires close monitoring and could inflame village rivalry. Therefore, the first step in implementing the Plan would be the marking of a Protected Nesting Area. This would introduce the concept of conservation to the collectors, indicate what the collectors are prepared to respect and provide an undisturbed site for comparison with the others. Central to protecting an area will be the placing of traditional tabus by the landowners, including the use of "kastom" markers such as the cycad tree, as well as notice boards in Bislama. One landowner suggested it would be advantageous to build a small centre at Buwoma to re-establish respect for land ownership; this could also be a point of information and be used as a base by researchers. Information boards should warn of fire hazards and the effect of dogs left behind. These measures will be supported by laws including the 1988 Wild Bird Protection Act (Department of Agriculture), and if necessary the passing of a specific bye-law under Act 1 of 1994 (Tacconi 1995).

Complementary to setting aside a Protected Nesting Area there will be the need for a series of environmental initiatives appropriate to a village context in Vanuatu. Workshops with village and church leaders, egg collectors, women's groups and schoolchildren are needed to disseminate information about the status, laws, ecology and threats to the Vanuatu Megapode. VPAI have approached the established Wan Smol Bag community theatre group who are receptive to running educational drama. Similar to Ntlamoa-Baidu's (1995) findings in Ghana, the concept of sustainability is engrained in traditional beliefs but, when a species is endemic, there is a need to emphasize the contribution individuals can make to ensure its survival. Radio broadcasts are important, and could be supplemented by newspaper articles.

As suggested by Bowen (1996) a closed season for hunting and egg collecting would be beneficial to ensure some eggs hatch. However, since the Wild Bird Protection Act (1962) is not recognized by the people on Ambrym (a licence is necessary to collect eggs or kill adult megapodes between I July and 31 March), this should only be enforced following an educational awareness programme. The situation is similar to the traditional collecting of eggs of the Moluccan Megapode on Banggai Islands, Indonesia (Argeloo and Dekker 1996). 


\section{Conclusion}

Since the villagers are committed to ensuring that future generations can continue to collect megapode eggs, the outlook for the Vanuatu Megapode on Ambrym is promising. However, research is needed to develop population models to interpret monitoring data. Overall population size and projected decline rates could then be extrapolated for the whole of Vanuatu and tested against the IUCN (1996) criteria. The number of megapodes needs to remain above a critical threshold where traditional exploitation can be sustained.

\section{Acknowledgements}

Many thanks go to Jenny Bowen (surveyor 1995) and Roy Hills (surveyor 1995 and 1996). Also thanks to Sharon Birks, Rene Dekker and Alison Stattersfield for their comments on drafts of the paper, Ken Davis, and to Chief Willie Bongmatur and Temar Rengreng on Ambrym, who all contributed to the success and enjoyment of the fieldwork. Also many thanks to the FFI for the grant from the $100 \%$ Fund; to Jane Weale for her donation; and to Subbuteo Natural History Books for the texts on megapodes.

\section{References}

Argeloo, M. and Dekker, R. W. R. J. (1996) Exploitation of megapode eggs in Indonesia: the role of traditional methods in the conservation of megapodes. Oryx 30:59-64.

Bowen, J. (1996) Notes on the Vanuatu Megapode Megapodius layardi on Ambrym, Vanuatu. Bird Conserv. Internatn. 6: 401-408.

Bregulla, H. L. (1992) Birds of Vanuatu. Shropshire: Anthony Nelson.

Collar, N. J., Crosby, M. J., and Stattersfield, A. J. (1994) Birds to watch 2: the world list of threatened birds. Cambridge, U.K.: BirdLife International (BirdLife Conservation Series no. 4)

Dekker, R. W. R. J. (1988) Notes on ground temperatures at nesting sites of the Maleo Macrocephalon maleo (Megapodiidae). Emu 88: 124-127.

Dekker, R. W. R. J. (1989) Predation and the western limits of megapode distribution (Megapodiidae; Aves). J. Biogeogr. 16:317-321.

Dekker, R. W. R. J. and McGowan, P. J. K. (1995) Megapodes-an action plan for their conservation 1995-1999. Gland, Switzerland: IUCN.

IUCN (1996) The 1996 Red List of threatened animals. Gland, Switzerland: IUCN.

Jones, D. N., Dekker, R. W. R. J. and Roselaar, C. S. (1995) The megapodes. Oxford: Oxford University Press.

Ntlamoa-Baidu, Y. (1995) Conservation education in threatened species management in Africa. Bird Conserv. Internatn 5: 455-462.

Sankaran, R. (1995). The Nicobar Megapode and other avifauna of the Nicobar Islands. Status and Conservation. SACON-Technical Report 2. Salim Ali Centre for Ornithology and Natural History, Coimbatore, India.

Stattersfield, A. J., Crosby, M. J., Long, A. J. and Wege, D.C. (1998) Endemic bird areas of the World. Cambridge, U.K.: BirdLife International.

Tacconi, L. (1995) Participatory conservation in Malakula Island. Research Report 10, Vanuatu Forest Conservation Reports. University of New South Wales, Australia. 